\title{
IMPLEMENTASI TEKNOLOGI AUGMENTED REALITY PADA BUKU PANDUAN WUDHU BERBASIS MOBILE ANDROID
}

\author{
Erwin Setiawan ${ }^{1}$, Undang Syaripudin ${ }^{2}$, Yana Aditya Gerhana ${ }^{3}$ \\ ${ }^{1,2,3}$ Jurusan Teknik Informatika, Fakultas Sains dan Teknologi \\ Universitas Islam Negeri Sunan Gunung Djati Bandung \\ Jl. A.H. Nasution 105, Bandung 40614 Indonesia \\ 1erwin.setiawan@student.uinsgd.ac.id, ${ }^{2}$ undang.syaripudin@uinsgd.ac.id, ${ }^{3}$ yana.aditya@ rruinsgd.ac.id
}

\begin{abstract}
Abstrak-Augmented Reality (AR) adalah teknologi interaktif yang mampu memproyeksikan objek maya ke dalam objek nyata secara real time. Perkembangan teknologi AR dewasa ini telah memberikan banyak kontribusi ke dalam berbagai bidang [1]. Salah satu implementasi AR di bidang edukasi seperti $A R$ Book. Buku merupakan salah satu media pembelajaran yang banyak digunakan. Selain itu, buku jg digunakan sebagai alat berkomunikasi oleh guru maupun orang tua terhadap anakanak, misalkan seperti jenis buku panduan mengenai tatacara wudhu. Wudhu adalah suatu bentuk peribadatan kepada Allah Ta'ala dengan mencuci anggota tubuh tertentu dengan tata cara yang khusus, wudhu khususnya diperintahkan sebelum melaksankan ibadah shalat dan thawaf. Umat muslim harus mengetahui tatacara berwudhu yang benar. Salah satu sistem operasi yang digunakan mobilephone atau smartphone yaitu android. Android adalah sebuah sistem operasi untuk perangkat mobile yang berbasis linux yang bersifat open source. Dengan memanfaatkan media mobile untuk membangun aplikasi menggunakan teknologi augmented reality sebagai media pembelajaran aplikasi $A R$ berbasis Mobile mempunyai keunggulan karena sifatnya yang mudah berpindah.
\end{abstract}

Kata Kunci: Augmented Reality, buku, wudhu, Android.

\section{PENDAHULUAN}

Setiap kegiatan ibadah umat Islam pasti melakukan thaharah (bersuci) terlebih dahulu seperti berwudhu. Wudhu adalah sebuah syariat kesucian yang Allah 'azza wa jalla tetapkan kepada kaum muslim sebagai syarat sebelum melaksanakan ibadah shalat.

"Hai orang-orang yang beriman, apabila kamu hendak mengerjakan shalat, Maka basuhlah mukamu dan tanganmu sampai dengan siku, dan sapulah kepalamu dan (basuh) kakimu sampai dengan kedua mata kaki." (QS. Al-Maidah: 6).

Selain dilakukan sebelum melaksanakan ibadah shalat menurut Jumhur 'ulama mengatakan bahwa melakukan wudhu dianjurkan sebelum melakukan ibadah thawaf di ka'bah, memegang mushaf Al-qur'an dan ibadah lainnya. Pada wudhu terkandung sebuah hikmah yang mengisyaratkan kepada kita bahwa hendaknya seorang muslim memulai ibadah dan kehidupannya dengan kesucian lahir batin. Oleh karena itu, umat muslim harus mengetahui tatacara berwudhu yang sesuai syariat islam.

Buku merupakan sebuah media atau alat informasi yang mungkin sudah ada sejak ratusan tahun yang lalu, selain berfungsi sebagai tempat menyimpan atau menyampaikan berbagai informasi, baik bersifat umum maupun khusus. Buku merupakan salah satu media pembelajaran yang banyak digunakan dan buku digunakan sebagai alat berkomunikasi oleh guru maupun orang tua terhadap anak-anak, misalkan seperti jenis buku panduan mengenai tatacara wudhu. Tetapi penyampaian informasi pada buku panduan wudhu hanya berupa teks dan gambar-gambar 2D. Pembelajaran tata cara wudhu masih menggunakan cara konvensional, murid melihat buku panduan dan guru menjelaskan bagaimana tatacara berwudhu.

Augmented reality sangat potensial sebagai sarana edukasi. Salah satu keuntungan yang dapat diperoleh dari aplikasi AR untuk tujuan edukasi 
yaitu meningkatkan pemahaman objek yang sedang dipelajari. AR lebih efektif sebagai media pembelajaran lainnya dibandingkan dengan media yang lain seperti buku, video, maupun penggunaan komputer biasa[2].

Salah satu sistem operasi mobile yang digunakan oleh smartphone adalah Android, Android juga dapat menggunakannya sebagai media edukasi. Karena android sebagai sistem operasi open source, pengguna dapat dengan mudah menginstal aplikasi pihak ketiga dari market App dan bahkan dari sumber tidak bisa diandalkan[3].

Berdasarkan latar belakang tersebut, terbentuklah tugas akhir yang berjudul "IMPLEMENTASI TEKNOLOGI AUGMENTED REALITY PADA BUKU PANDUAN BERWUDHU BERBASIS MOBILE ANDROID" Dengan harapan bisa bermanfaat dalam pembelajaran tatacara gerakan wudhu menjadi lebih menarik dan menyenagkan.

\section{A. Augmented Reality}

Augmented reality (AR) merupakan penggabungan benda-benda nyata dan maya di lingkungan nyata, berjalan secara interaktif dalam waktu nyata, dan terdapat integrasi antar benda dalam tiga dimensi, yaitu benda maya terintegrasi dalam dunia nyata. Penggabungan benda nyata dan maya dimungkinkan dengan teknologi tampilan yang sesuai, interaktivitas dimungkinkan melalui perangkat-perangkat input tertentu, dan integrasi yang baik memerlukan penjejakan yang efektif[4].

Selain menambahkan benda maya dalam lingkungan nyata, Augmented Reality juga berpotensi menghilangkan benda-benda yang sudah ada. Menambah sebuah lapisan gambar maya dimungkinkan untuk menghilangkan atau menyembunyikan lingkungan nyata dari pandangan pengguna. Misalnya, untuk menyembunyikan sebuah meja dalam lingkungan nyata, perlu digambarkan lapisan representasi tembok dan lantai kosong yang diletakkan di atas gambar meja nyata, sehingga menutupi meja nyata dari pandangan pengguna.

Augmented Reality dapat diaplikasikan untuk semua indera, termasuk pendengaran, sentuhan, dan penciuman. Selain digunakan dalam bidangbidang seperti kesehatan, militer, industri manufaktur, Augmented Reality juga telah diaplikasikan dalam perangkat-perangkat yang digunakan orang banyak, seperti pada telepon genggam.

\section{B. Metode Augmented Reality}

Marker merupakan suatu pola yang dibuat dalam bentuk gambar dan dapat dikenali oleh perangkat optik atau kamera pada metode Augmented reality. Sebuah marker yang baik adalah marker yang mudah dikenali dan bersifat reliable dalam kondisi apapun[5].

Misalnya dalam kondisi cahaya yang kurang dan posisi kamera yang berpindah-pindah, maka marker yang baik akan tetap terbaca oleh system AR. Oleh karena itu, marker yang baik memiliki tekstur yang rumit. Metode pada Augmented reality dapat dibagi menjadi tiga yaitu:

1) Marker Based Tracking.

2) Markerless Augmented Reality.

3) Oculation based augmented reality.

\section{Markerless Augmented Reality}

Markerless merupakan salah satu teknologi tracking yang menggunakan gambar sebagai markernya. Metode ini tidak menggunakan frame marker sebagai objek yang dideteksi. Proses tracking ini menggunakan tekstur gambar yang disimpan dalam database sebagai sumber referensinya dan membandingkan tekstur yang tertangkap oleh kamera perangkat dengan tekstur yang ada di database markernya.

\section{Algoritma Fast Corner Detectiom}

Vuforia menggukan algoritma FAST Corner Detection untuk mendefenisikan seberapa baik gambar dapat dideteksi dan dilacak menggunakan Vuforia SDK. FAST Corner Detection yaitu pendeteksian dengan mencari titik-titik (insert point) atau sudut (corner) pada suatu gambar. FAST Corner Detection dimulai dengan menentukan suatu titik p pada koordinat (Xp, Yp) pada citra dan membandingkan intensitas titik $\mathrm{p}$ dengan 4 titik disekitarnya. Titik pertama terletak pada koordinat (x, yp-3), titik kedua terletak 40 pada koordinat $(x p+3, y)$, titik ketiga terletak pada koordinat $(\mathrm{x}, \mathrm{yp}+3)$, dan titik keempat terletak pada koordinat (xp-3, y).

Jika nilai intensitas di titik $\mathrm{p}$ bernilai lebih besar atau lebih kecil daripada intensitas sedikitnya tiga titik disekitarnya ditambah dengan suatu intensitas batas ambang (Threshold), maka dapat dikatakan bahwa titik $\mathrm{p}$ adalah suatu sudut. Setelah itu titik $p$ akan digeser ke posisi( $x p+1, y p)$ dan melakukan intensitas keempat titik disekitarnya lagi. Iterasi ini terus dilakukan sampai semua titik pada citra sudah dibandingkan.

\section{E. Vuforia SDK}


Vuforia Software Development Kit (SDK). Yang dikembangkan oleh Qualcomm yang memungkinkan seorang developer untuk membuat aplikasi berbasis teknologi augmented reality. Dulu lebih dikenal dengan QCAR (Qualcomm Company Augmented reality). Ditambah menggunakan teknologi Computer Vision untuk mengenali dan melacak gambar planar (Target Image) dan objek 3D sederhana seperti kotak secara real-time. Dengan support iOS, Android dan Unity3D, platform Vuforia mendukung para pengembang untuk membuat aplikasi yang dapat digunakan di hampir seluruh jenis smartphone.

\section{F. Unity}

Unity merupakan salah satu game engine yang banyak digunakan. Unity menyediakan fitur pengembangan game dalam berbagai platform, yaitu Unity Web, Windows, Mac, Android, iOS, XBox, Playstation 3 dan Wii. Dan kabarnya, Unity akan merilis versi berikutnya dengan dilengkapi platform Flash.

Adapun fitur-fitur yang dimilik oleh Unity 3D antara lain sebagai berikut:

1. Integrated development environment (IDE) atau lingkungan pengembangan terpadu.

2. Penyebaran hasil aplikasi pada banyak platform.

3. Engine grafis menggunakan Direct3D (Windows), OpenGL (Mac, Windows), OpenGL ES (iOS), and proprietary API (Wii).

4. Game Scripting melalui Mono. Scripting yang dibangun pada Mono, implementasi open source dari NET Framework. Selain itu Pemrogram dapat menggunakan UnityScript (bahasa kustom dengan sintaks JavaScriptinspired), bahasa C \# atau Boo (yang memiliki sintaks Python-inspired)[6].

\section{G. Blender}

Blender adalah sebuah software 3D suite yang boleh dikatakan salah satu yang terlengkap diantara software-softwareopen source. Tool-tool yang disediakan sederhana, namun sudah mencakup seluruh kebutuhan untuk pembuatan pemodelan 3D dan film animasi[7].

Kelebihan dari software blender yaitu Open Source, Multi platform, Update, Free, lengkap dan ringan.

\section{H. Sistem Operasi Android}

Android adalah sebuah sistem operasi untuk perangkat mobile berbasis linux yang mencakup sistem operasi, middleware, dan aplikasi. Android menyediakan platform terbuka bagi para pengembang untuk menciptakan sebuah aplikasi. Android merupakan generasi baru platform mobile yang memberikan keleluasaan kepada pengembang untuk melakukan pengembangan sesuai yang diinginkan. Tidak hanya menjadi system operasi di Smartphone, saat ini Android menjadi pesaing utama Apple pada sistemoperasi Tablet PC. Pesatnya pertumbuhan Android disebabkan karena Android merupakan platform yang sangat lengkap baik dari system operasinya, aplikasi dan tool pengembangnya[8].

\section{PERANCANGAN SISTEM}

1. Use Case Diagram

Perancangan Use Case DiagramAplikasi AR wudhu dapat dilihat pada Gambar 3.2.

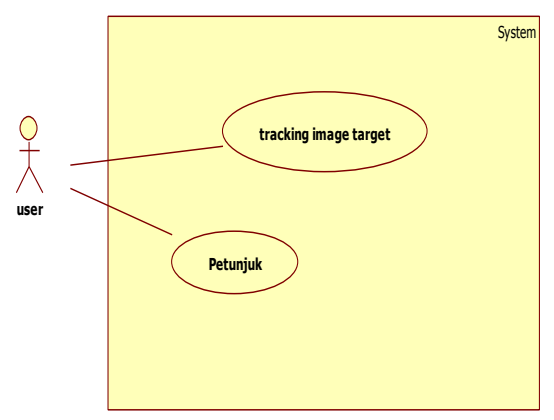

Gambar 3.2 Use case Diagram

2. Class Diagram

Perancangan class diagram AR wudhu dapat dilihat pada gambar berikut:

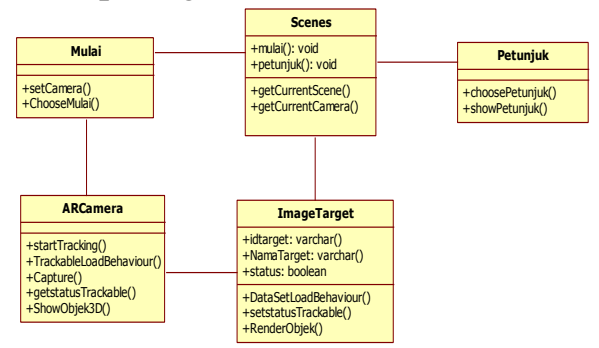

Gambar 3.3 Class Diagram

3. Sequence Diagram

a. Sequence diagram Tracking Image target

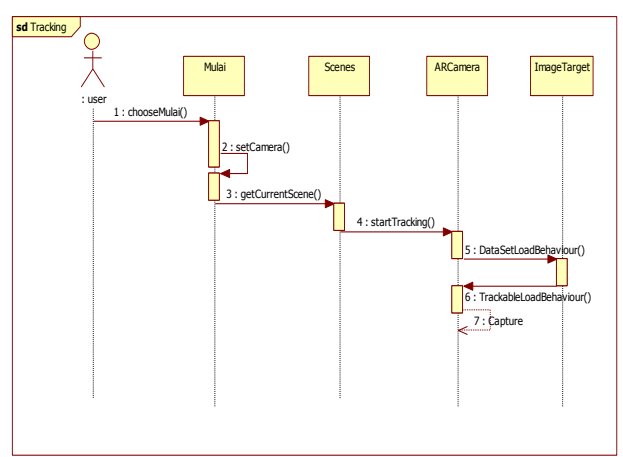

Gambar 3.4 Sequence diagram Tracking image target 
b. Sequence diagram Deteksi Image target

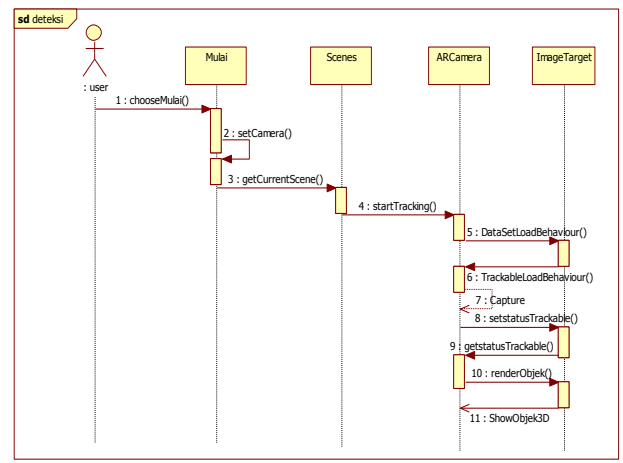

Gambar 3.5 Sequence diagram Deteksi image target

c. Sequence diagran petunjuk

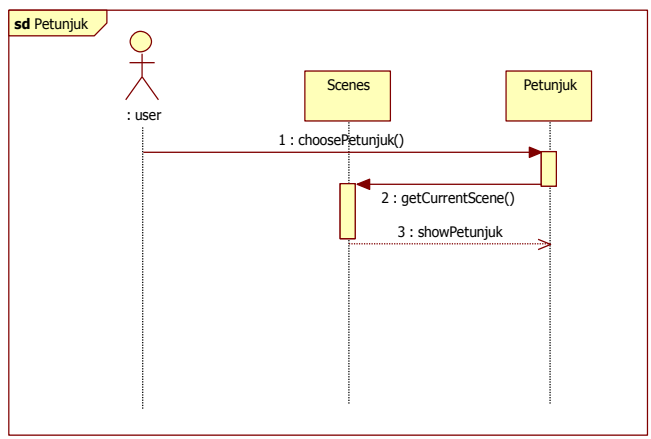

Gambar 3.6 Sequence diagram Petunjuk

\section{Activity Diagram}

Diagram aktivitas atau activity diagram menggambarkan workflow (aliran kerja) atau aktivitas dari sebuah sistem atau proses bisnis.

a. Activity Diagram Tracking image target

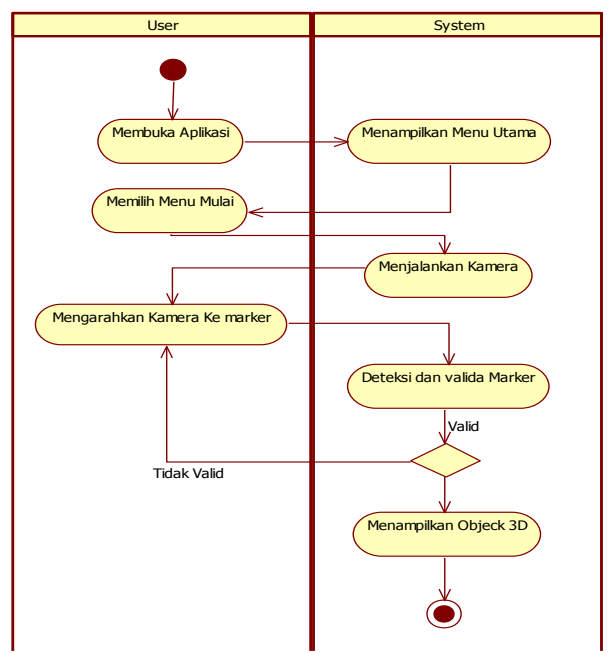

Gambar 3.7Activity Diagram Tracking image target

Pada gambar 3. menunjukkan aktivitas pengguna untuk memulai tracking image target. Pada proses ini pemgguna memilih tombol mulai pada menu. Dan sistem menampilkan kamera kemudian pengguna mengarahkan kamera ke marker dan sistem menampilkan objek 3D gerakan wudhu sesuai dengan gambar marker.

b. Activity Diagram Petujuk

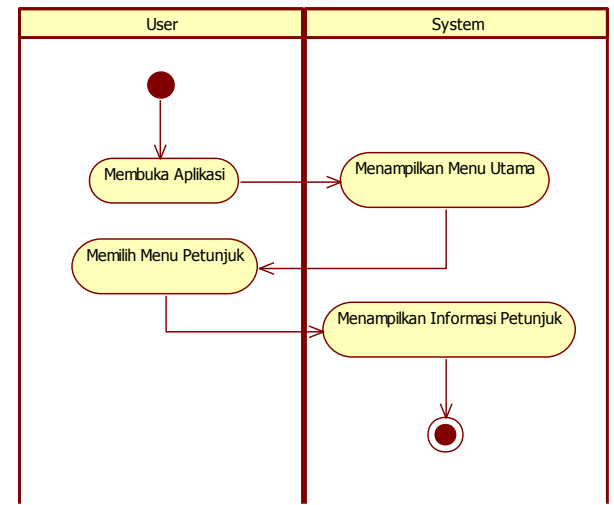

Gambar 3.8Activity Diagram Petunjuk

Pada gambar 3.8 menunjukkan aktivitas pemain untuk melihat halaman petunjuk penggunaan aplikasi AR wudhu.

\section{IMPLEMENTASI}

\section{A. Implementasi User Interface}

1. Tampilan Splashscreen

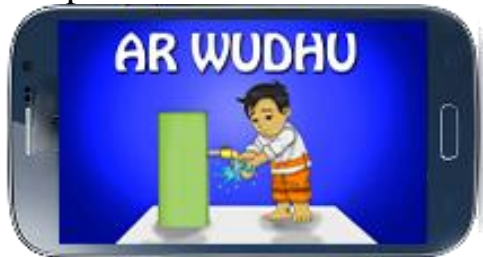

Gambar 4.1 Antarmuka Halaman Splashscreen Tampilan pada gambar 4.1 merupakan tampilan logo dari aplikasi permainan pada saat pemain membuka aplikasi pertama kali.

2. Tampilan Menu Utama

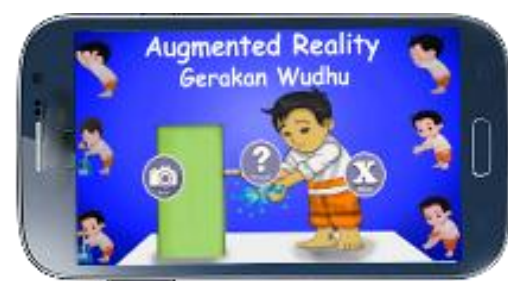

Gambar 4.2 Menu Utama

Tampilan pada gambar 4.2 merupakan tampilan main menu dari aplikasi AR wudhu, terdapat tiga tombol menu yaitu tombol mulai untuk memulai aplikasi, tombol Petunjuk untuk memberikan penjelasan mengenai cara menggunakan aplikasi dan tombol keluar untuk menghentikan aplikasi.

3. Tampilan Menu Mulai 
Tampilan gambar 4.3 merupakan tampilan menu mulai pada aplikasi AR wudhu.

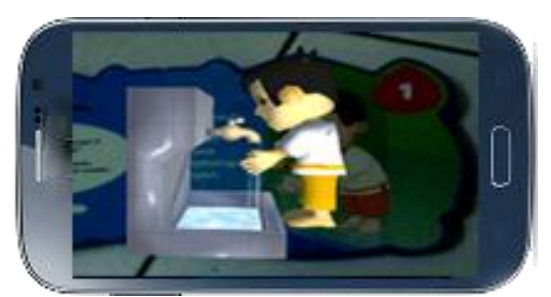

Gambar 4.3 Menu mulai

Pada menu mulai pengguna aplikasi mengarahkan kamera ke marker buku wudhu maka sistem akan menampilkan objek 3D gerkan wudhu sesuai gambar pada marker.

4. Tampilan Menu Petunjuk

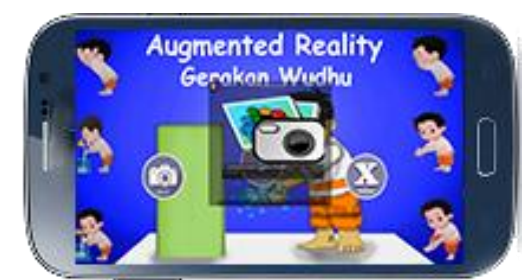

Gambar 4.4 Menu Petunjuk

Tampilan gambar 4.4 merupakan tampilan menu petunjuk aplikasi AR wudhu. Pada menu ini terdapat informasi cara penggunaan aplikasi AR wudhu.

\section{B. Pengujian}

Pengujian sistem merupakan proses untuk menjalankan perangkat lunak untuk mencari kesalahan atau kekurangan pada perangkat lunak yang diuji dan menentukan apakah perangkat lunak layak seperti spesifikasi sistem yang diinginkan. Metode pengujian yang digunakan dalam penelitian tugas akhir ini adalah metode pengujian Alpha-Beta.

1. Pengujian Aplha

Pengujian Alpha merupakan pengujian yang dilakukan dengan mencari kesalahan pada sebuah sistem yang berfokus pada persyaratan fungsional perangkat lunak yang dibangun. Pengujian ini menggunakan pengujiann blackbox. Pengujian black-box berfokus pada persyaratan fungsionalitas sistem yang dibangun.

Hasil pengujian dapat dilihat pada tabel Pengujian aplikasi dibawah ini:

Tabel 4.1 Uji Menu Mulai

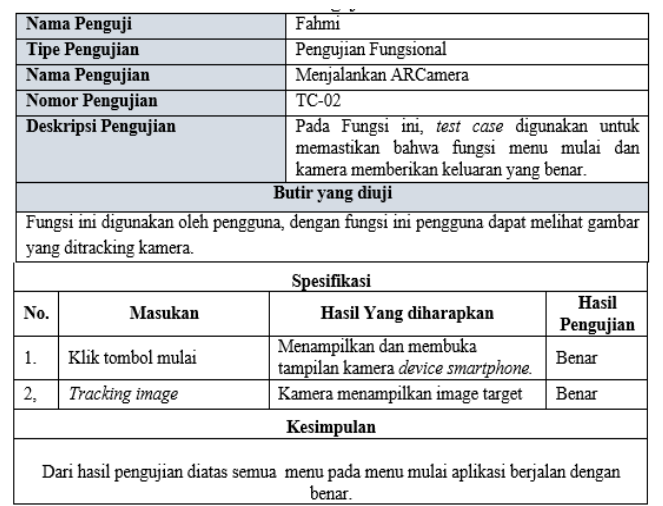

Tabel 4.2 Uji Main Menu

\begin{tabular}{|c|c|c|c|}
\hline \multicolumn{2}{|c|}{\begin{tabular}{|l} 
Nama Penguji \\
\end{tabular}} & \multicolumn{2}{|l|}{ Fahmi } \\
\hline \multicolumn{2}{|c|}{ Tipe Pengujian } & \multicolumn{2}{|l|}{ Pengujian Fungsional } \\
\hline \multicolumn{2}{|c|}{ Nama Pengujian } & \multicolumn{2}{|c|}{ Menampilkan seluruh tombol menu aplikasi } \\
\hline \multicolumn{2}{|c|}{ Nomor Pengujian } & \multicolumn{2}{|l|}{ TC-01 } \\
\hline \multicolumn{2}{|c|}{ Deskripsi Pengujian } & \multicolumn{2}{|c|}{$\begin{array}{l}\text { Pada Fungsi ini, test case digunakan untuk memastikan } \\
\text { bahwa fungsi semua tombol menu memberikan keluaran } \\
\text { yang benar. }\end{array}$} \\
\hline \multicolumn{4}{|c|}{ Butir yang diuji } \\
\hline \multicolumn{4}{|c|}{$\begin{array}{l}\text { Fungsi ini digunakan oleh pengguna, dengan fungsi ini pengguna dapat melihat semua menu dar } \\
\text { memilih menu pada aplikasi. }\end{array}$} \\
\hline \multicolumn{4}{|c|}{ Spesifikasi } \\
\hline No & Masukan & Hasil Yang diharapkan & Hasil Pengujian \\
\hline 1. & Klik tombol mulai & $\begin{array}{l}\text { Menampilkan dan membuka } \\
\text { tampilan kamera device } \\
\text { smartphone }\end{array}$ & Benar \\
\hline 2, & Klik tombol Petunjuk & Menampilkan halaman petunjuk & Benar \\
\hline 3. & Klik tombol keluar & Keluar dari aplikasi & Benar \\
\hline
\end{tabular}

Tabel 4.3 Uji Tracking Image target

\begin{tabular}{|c|c|c|c|}
\hline \multicolumn{2}{|c|}{ Nama Penguji } & \multicolumn{2}{|l|}{ Fahmi } \\
\hline & Pengujian & \multicolumn{2}{|l|}{ Pengujian Fungsional } \\
\hline \multicolumn{2}{|c|}{ Nama Pengujian } & \multicolumn{2}{|c|}{ Menampilkan objek 3D gerakan wudhu } \\
\hline \multicolumn{2}{|c|}{ Nomor Pengujian } & \multicolumn{2}{|c|}{ TC-03 } \\
\hline \multicolumn{2}{|c|}{ Deskripsi Pengujian } & \multicolumn{2}{|c|}{$\begin{array}{l}\text { Pada Fungsi ini, test case digunakan untuk } \\
\text { memastikan bahwa fungsi deteksi image target } \\
\text { memberikan keluaran yang baik dan benar. }\end{array}$} \\
\hline \multicolumn{4}{|c|}{ Butir Yang diuji } \\
\hline \multicolumn{4}{|c|}{$\begin{array}{l}\text { Fungsi ini digunakan oleh pengguna, dengan fungsi ini pengguna dapat melihat objek } \\
\text { 3D augmented yang keluar dari kamera aplikasi. }\end{array}$} \\
\hline \multicolumn{4}{|c|}{ Spesifikasi } \\
\hline No. & Masukan & Hasil Yang diharapkan & $\begin{array}{c}\text { Hasil } \\
\text { Pengujian }\end{array}$ \\
\hline 1. & $\begin{array}{l}\text { Gambar marker membasuh } \\
\text { tangan }\end{array}$ & $\begin{array}{l}\text { Menampilkan objek 3D membasuh } \\
\text { tangan }\end{array}$ & Benar \\
\hline 2. & Gambar marker berkumur & Menampilkan objek 3D berkumur & Benar \\
\hline 3. & $\begin{array}{l}\text { Gambar marker } \\
\text { membersihkan hidung }\end{array}$ & $\begin{array}{l}\text { Menampilkan objek 3D } \\
\text { membersihkan hidung }\end{array}$ & Benar \\
\hline 4. & $\begin{array}{l}\text { Gambar marker } \\
\text { membersihkan muka }\end{array}$ & $\begin{array}{l}\text { Menampilkan objek 3D } \\
\text { membersihkan muka }\end{array}$ & Benar \\
\hline 5. & $\begin{array}{l}\text { Gambar marker membasuh } \\
\text { tangan }\end{array}$ & $\begin{array}{l}\text { Menampilkan objek 3D membasuh } \\
\text { tangan }\end{array}$ & Benar \\
\hline 6. & $\begin{array}{l}\text { Gambar marker membasuh } \\
\text { kepala }\end{array}$ & $\begin{array}{l}\text { Menampilikan objek 3D membasuh } \\
\text { kepala }\end{array}$ & Benar \\
\hline 7. & $\begin{array}{l}\text { Gambar marker membasuh } \\
\text { telinga }\end{array}$ & $\begin{array}{l}\text { Menampilkan objek 3D membasuh } \\
\text { telinga }\end{array}$ & Benar \\
\hline 8. & $\begin{array}{l}\text { Gambar marker membasuh } \\
\text { kaki }\end{array}$ & $\begin{array}{l}\text { Menampillkan objek 3D membasuh } \\
\text { kaki }\end{array}$ & Benar \\
\hline 9. & $\begin{array}{l}\text { Gambar marker dari buku } \\
\text { lain yang belum di } \\
\text { inisialiasi }\end{array}$ & Tidak menampilkan objek 3D & Benar \\
\hline \multicolumn{4}{|c|}{ Kesimpulan } \\
\hline & & dapat menampilkan objek 3D apa & engggunakan \\
\hline
\end{tabular}

\section{Pengujian Beta}

Pengujian betha merupakan pengujian yang dilakukan dengan tujuan untuk mengetahui sejauh mana kualitas sistem pada aplikasi yang dibangun, apakah sudah memenuhi harapan atau belum. Untuk itu dalam pengujian betha dilakukan penelitian terhadap responden atau pengguna sistem dengan melakukan pengumpulan data menggunakan kuesioner atau angket. 
Dalam melakukan pencarian persentase dari masing-masing jawaban dapat menggunakan rumus:

$$
\mathrm{Y}=\frac{T S}{\text { Skor ideal }} \mathrm{X} 100 \%
$$

Keterangan :

$\mathrm{Y}=$ Nilai presentase.

$\mathrm{TS}=$ Total skor responder $=\Sigma$ bobot $\mathrm{x}$ frekuensi.

Skor ideal $=$ Bobot maksimal $\mathrm{x}$ jumlah responden $=5 \mathrm{x} 20=100$

Tabel 4.4 Hasil Penilaian

\begin{tabular}{|c|l|c|}
\hline \multirow{2}{*}{ NO } & \multicolumn{2}{|c|}{ Peniaian } \\
\cline { 2 - 3 } & \multicolumn{1}{|c|}{ Aspek Yang dinilai } & Persentase \\
\hline 1 & Kegunaan dan Manfaat Aplikasi & $87 \%$ \\
\hline 2 & Ketertarikan Mengguakan Aplikasi & $85 \%$ \\
\hline 3 & Pengoperasian Aplikasi & $76 \%$ \\
\hline 4 & Konten animasi & $80 \%$ \\
\hline
\end{tabular}

\section{A. Kesimpulan}

\section{KESIMPULAN}

Berdasarkan hasil yang didapat dari penelitian tugas akhir yang berjudul: "Impelementasi Teknologi Augmented Reality Pada Buku Panduan Wudhu Berbasis Mobile Android". Maka dapat diambil kesimpulan sebagai berikut :

1. Telah dirancang dan dibangun aplikasi augmented reality wudhu pada perangkat mobile android sebagai media pembelajaran untuk anak-anak dalam mengenali tata cara gerakan wudhu berbentuk simulasi animasi gerakan wudhu yang dibangun dengan menggunakan game engine Unity 3D, Vuforia SDK dan blender sebagai tool untuk membuat model animasi model 3D.

2. Metode markerless augmented reality dapat diterapkan pada aplikasi augmented reality wudhu pada buku panduan wudhu sebagai media pembelajaran untuk anak-anak. Dengan menggunakan metode markerless dapat mempermudah untuk pembuatan markernya dan lebih menarik yaitu dengan menggunakan gambar halaman buku panduan wudhu dibandingkan dengan menggunakan marker hitam putih.

\section{B. Saran}

Adapun saran-saran untuk mengembangan penelitian kedepannya sebagai berikut:

1. Antar muka aplikasi augmented realty wudhu pada perangkat android yang dibuat agar lebih bagus dan animasi diperhalus serta penambahan audio agar lebih interaktif.
2. Penggunaan marker tidak hanya menggunakan buku/poster tetapi dapat juga menggunakan media lain dilingkungan sekitar kita.

\section{DAFTAR PUSTAKA}

[1] Yuen, S. C.-Y., Yaoyuneyong, G., \& Johnson, E. 2011. "Augmented Reality: An Overview and Five Directions for AR in Education". Journal of Educational Technology Development and Exchange, 119-140.

[2]Radu, I. 2012. Why should my students use AR? A comparative review of the educational impacts of augmented-reality. Mixed and Augmented Reality (ISMAR), IEEE International Symposium (pp.313-314).

[3] Bala, Kiran., Sharma, Sumit., Kaur, Gurpreet. 2015. "A Study on Smartphone based Operating System". International Journal of Computer Applications (0975 - 8887).

[4] Azuma, Ronald T. Aug. 1997. "A Survey of Augmented Reality". In Presence: Teleoperators and Virtual Environments 6, 4, 355-385.

[5] Siltanen, S. 2012. Theory and applications of marker-based augmented reality. Finland. 42

[6] Rizki, Yoze. 2012. "Markerless Augmented Reality Pada Perangkat Android". Jurnal Teknik Elektro. Institut Teknologi Surabaya.

[7] Fidelis, Joshapat Soekahar. 2004 : "Open Source 3D Animation Blender Publisher". Jakarta.

[8]Safaat, Nazruddin. 2011. Pemograman Aplikasi Mobile Smartphone dan Tablet PC Berbasis Android. Informatika: Bandung. 